\title{
To the knowledge of Chrysomelidae (Coleoptera) from the islands of southern Vietnam
}

\author{
К познанию зкуков-листоедов (Coleoptera, Chrysomelidae) \\ с островов южного Вьетнама
}

\author{
M.O. Skomorokhov \\ M.O. Скоморохов
}

Institute for Problems of Ecology and Evolution, Russian Academy of Sciences, Leninsky prospect 33, Moscow 119071 Russia. Институт проблем экологии и эволюции РАН, Ленинский проспект 33, Москва 119071 Россия.

KEY WORDS. Chrysomelidae, Vietnam, islands, new species.

КЛЮЧЕВЫЕ СЛОВА. Chrysomelidae, Вьетнам, острова, новые виды.

ABSTRACT. Two new species of Chrysomelidae: Plagiodera multilineata sp.n. and Pyrrhalta prokofievi sp.n. are described from islands Con Dao and Phu Quoc, south Vietnam.

РЕЗЮМЕ. С островов Кондао и Фукуок (юг Вьетнама) описаны два новых вида жуков-листоедов: Plagiodera multilineata sp.n. and Pyrrhalta prokofievi sp.n.

\section{Introduction}

The beetle family Chrysomelidae is intensively studied in continental Indo-China, but very peculiar fauna of off-coast islands has been almost unstudied yet. I received from my college A. Prokofiev about 25 leafbeetle species, originated from Phu Quoc and Con Dao islands (South Vietnam), , and discovered, that a few of them are new to science. Two of them are described below. The holotypes of both species are deposited in the collection of the Zoological Institute, St. Petersburg; two paratypes of Plagiodera multilineata in the same museum, two other in the collection of L.N. Medvedev (Moscow), and another five in my collection.

Plagiodera multilineata Skomorokhov, sp.n.

TYPE MATERIAL. Holotype: O', S.Vietnam, Phu Quoc island, $5 \mathrm{~km}$. W Ham Ninh, 26.11.2010, A.Prokofiev leg. Paratypes: The same data as the holotype, 8 ex.

DESCRIPTION of holotype. Body orange-yellow. 8$11^{\text {th }}$ antennomeres black, $7^{\text {th }}$ - partly black. Scutellum piceous, with orange tint. Elytra yellow with black suture and five long black stripes on each; the fourth stripe curved to the third at front and back ends and connected with it (Fig. 1). Black colour is without metallic lustre.

Head feebly shining, shagreened. Frons and vertex covered by small punctures, interspaces 1.5-2.0 times larger than diameter of punctures; punctuation of clypeus is smaller and sparse. Frons with a small depression on each side between median groove and eye. Antenna short, 6-11 antennomeres widened and forming a club, weakly separated from other antennomeres. Ratio of lengths of antennomeres as: $18-7-8-$ 10-8-8-8-9-10-9-16. Clubbed antennomeres covered by dense short hairs, almost dull.

Pronotum 2.5 times broader than long, widest near obtuse posterior angles; narrowed straightly in posterior half and roundly in anterior half to the rounded anterior angles. All margins bordered, basal border in central part is very poorly developed. Disc convex, shining, finely and sparsely punctured, with larger and denser punctures near sides and anterior angles. Scutellum triangular, rounded apically, without punctures.

Elytra rounded, shining, as long as wide. Punctation is rather large and dense (interspaces as large as $0.8-1.5$ diameters of punctures); in most part of elytra some punctures forming short longitudinal rows. Interspaces between large punctures with very fine dense punctation (visible only with increase $32 \mathrm{x}$.). Lateral convexity with a row of punctures above the middle; and some not numerous punctures of the same size are under this row. Lateral explanate margin of elytra is very fine, hardly visible. There are two very small punctured depressions near apical angles of elytra, suture between them is ridge-like.

Prosternum smooth, dull; mesosternum hardly shining, with sparse punctation. Metasternum and abdomen ventrally shining, not punctured. Metepisterna with very large partly merged punctures. The first abdominal sternite without ridges near coxae. All sternites with shallow depressions laterally, surface of depressions is uneven. Legs short and stout; tibiae from the base to $1 / 3$ are strongly thickened, then their width are almost without change. About one half of $5^{\text {th }}$ tarsomere is free. Aedeagus (Figs 4, 6) strongly curved near basal bulb and is very thin in this place; widened to apical part which is triangular with truncate apex. Spermatheca was not be found in one dissected female.

Body length $4.70 \mathrm{~mm}$, width $-3.65 \mathrm{~mm}$.

Female. Morphologically practically identical with male.

VARIABILITY. Elytral black stripes varying in width; when they are narrow, external stripe may be shortened in posterior part and nearest to stripe - in frontal part, coloration of these stripes becomes brown, not black. Body length is 4.5 to $5.6 \mathrm{~mm}$.

DIAGNOSIS. Oriental Plagiodera Chevrolat, 1836species are not numerous. Only one of them is very close to the 

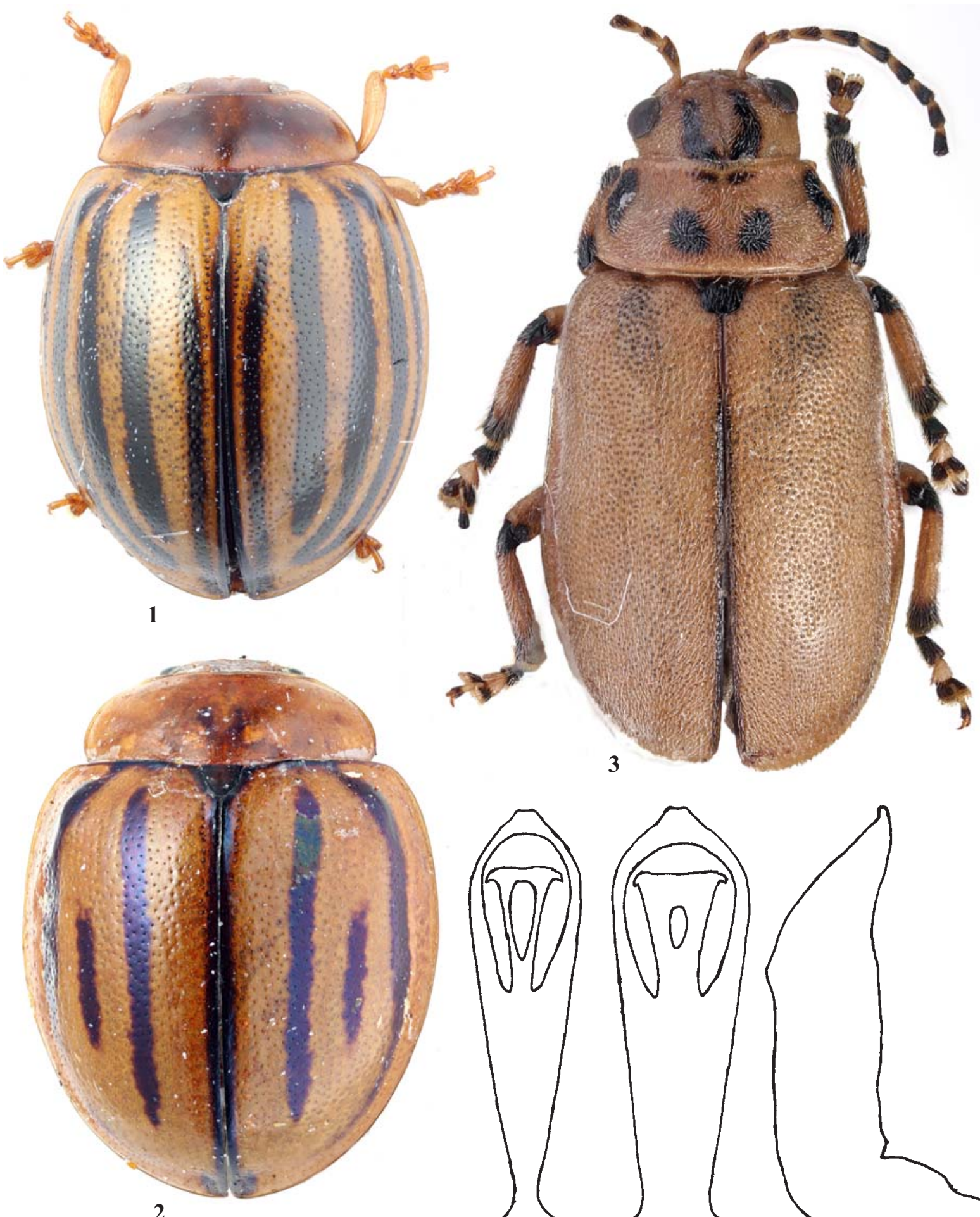

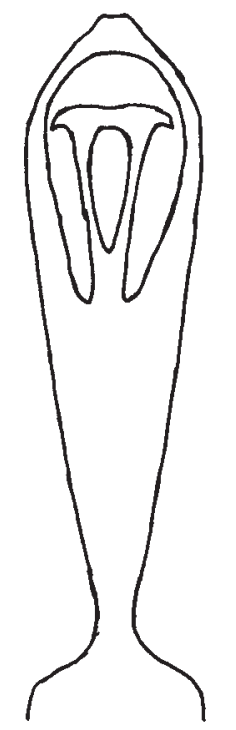

4

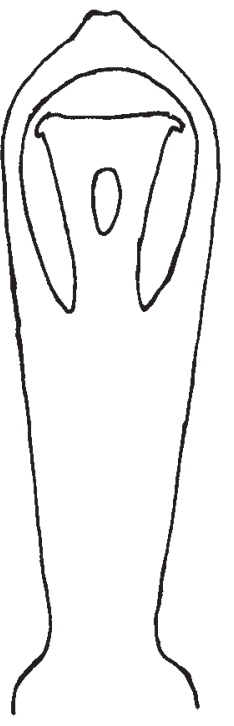

5

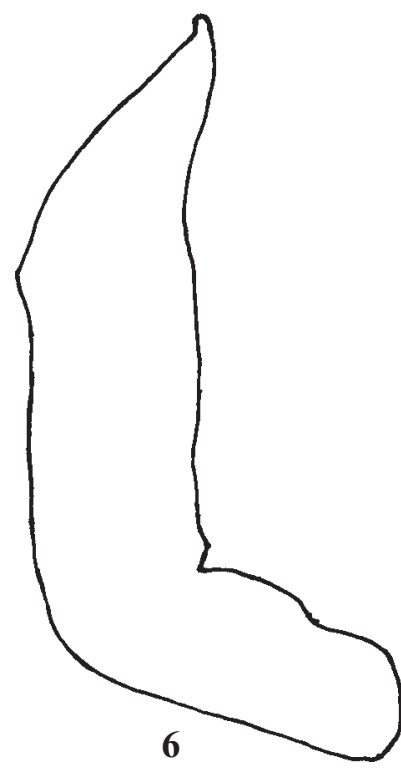

Figs 1-6. Chrysomelidae: 1,4 - Plagiodera multilineata sp.n.; 2, 5-P. septemvittata Stål; 3 - Pyrrhalta prokofievi sp.n.; 6 - both species of Plagiodera; 1-3 - general view; 4-6 - aedeagus; $1-5$ - dorsal view, 6 - lateral view.

Pис. 1-6. Chrysomelidae: 1, 4 - Plagiodera multilineata sp.n.; 2, 5 - P. septemvittata Stel; 3 - Pyrrhalta prokofievi sp.n.; 6 - оба вида Plagiodera; 1-3 - общий вид жуков; 4-6 - эдеагус; 1-5 - вид сверху, 6 - вид сбоку. 
new species: $P$. septemvittata Stål, 1858 (Fig. 2), distributed in South China, Vietnam, Taiwan, Philippines (Kimoto \& Gressitt, 1981). These two species are very similar: only differences in coloration are prominent. Moreover, aedeagus of the new species is more gracile and much more (about 5 times) narrowed at the base, then aedeagus of $P$. septemvittata (about 2 times) (Fig. 5). Covering plates of orifice also differ from each other in size and proportions (Figs 4-5). Aedeagi of both species are identical in lateral view (Fig. 6) These differences support the specific status of $P$. multilineata, not an island subspecies of widespread $P$. septemvittata. It is possible, that $P$. septemvittata is an ancestor of $P$. multilineata.

ETYMOLOGY. The name refers to the peculiar elytral pattern of the new species.

\section{Pyrrhalta prokofievi, sp.n.}

TYPE MATERIAL. Holotype: + , S. Vietnam, Con Dao island, natl. park, 7-9.12.2010. A. Prokofiev leg.

DESCRIPTION. Body oblong-oval, slightly widened to the level of hind third of elytra, rather densely pubescent (except the anterior half of the head) with short white hairs. Coloration of body (Fig. 3), except brownish abdomen, is light brownish-yellow with black: distal half of mandibles, two longitudinal stripes on vertex, closed to each other at hind end, two round spots near the base of pronotum in front of scutellum, two larger oval spots near fore angles of pronotum, scutellun, suture of elytra (except apical part), articulations of legs, apices of tibiae and first, third and apical half of fifth tarsomeres. Moreover, apical 2/3 of the upper surface of antennomeres $1-3$ is darkened and apical half of antennomeres 4-9 is black (antennomeres 10 and 11 absent). There are also two little transverse marks behind anterior border of pronotum near median line. Surface shining, without microsculpture.

Labrum transverse, smooth, with a transverse row of 8 setae, interrupted in the middle; its anterior margin sinuate. Interantennal space raised, smooth, forming small blunt ridge. Frontal tubercles transverse-oval, small, smooth, separated by clear groove, shallow on sides. Vertex with dense minute punctation and short hairs, with a longitudinal groove in middle. Antennae (antennomeres 10 and 11 absent) short, slender, with oblong antennomeres; ratio of lengths of antennomeres 1-9 as: $20-11-13-16-15-15-14-12-12$.

Pronotum transverse, 2.17 times broader then long, widest near the base, strongly and straightly narrowed to the anterior angles, which are with small teeths. Posterior angles obtuse angulate, almost rounded. Surface is slightly concave, uneven, but without distinct depressions; densely covered by rather large punctures, intersticies a little smaller than diameter of punctures. All margins are clearly bordered, except the anterior margin, its border is thin, hardly visible at the middle. All angles without setae (probably, they are broken). Proepipleurae smooth, shining. Scutellum subquadrate, with broadly rounded hind angles, smooth, with sparse pubescence.

Elytra oblong, 1.45 times as long as wide, with explanate margin (except the apical part); slightly and almost straightly widened to the apical third. Humeral calli well developed. Punctation is very dense, intersticies between punctures narrow, in some places rib-like, punctures large, equal with punctures of pronotum. Epipleura concave, covered by hairs, continued to the apical third of elytra. Wings absent. Thoracic sternites are almost smooth, abdominal ones with dense, but fine punctation. The $5^{\text {th }}$ sternite is sinuate in the middle, depth of the sinuation is $1 / 4$ of sternite length.

Body length is $7.25 \mathrm{~mm}$, width $3.65 \mathrm{~mm}$.

DIAGNOSIS. The genus Pyrrhalta Joannis, 1865 has been poorly studied in Indochina yet and is needed a revision. Fourteen species are known, only seven of them are keyed [Kimoto, 1989]. The other seven species were described by E.V.Samoderzhenkov [1988] and still not keyed. The new species is easily distinguished from all these species and other oriental Pyrrhalta species by its unique coloration.

ETYMOLOGY. The new species is dedicated to my college Artjom Prokofiev, who collected this species.

ACKNOWLEDGMENTS. I am grateful to my teacher in studying Chrysomelidae L.N. Medvedev for his critical reading and comments on the manuscript and to Dr. K.V. Makarov, who kindly helped with the photographs for this paper.

\section{References}

Kimoto S. 1989. Chrysomelidae (Coleoptera) of Thailand, Cambodia, Laos and Vietvam. IV. Galerucinae // Esakia. Vol.27. P.1241.

Kimoto S. \& Gressitt J.L. 1981. Chrysomelidae (Coleoptera) of Thailand, Cambodia, Laos and Vietnam. II. Clytrinae, Cryptocephalinae, Chlamisinae, Lamprosomatinae and Chrysomelinae // Pacific Insects. Vol.23. No.3-4. P.286-391.

Samoderzhenkov E.V. 1988. Zhuki-listoedy triby Galerucini (Chrysomelidae, Galerucinae) fauny Vietnama [Beetles of the tribe Galerucini (Chrysomelidae, Galerucinae) in the fauna of Vietnam ]//L.N. Medvedev, B.R. Striganova(eds.). Fauna i ekologiya nasekomykh Vietnama. Moskva: Nauka Publ. P.70-95. [inRussian] 